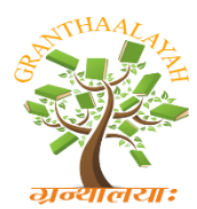

INTERNATIONAL JOURNAL OF RESEARCH GRANTHAALAYAH A knowledge Repository

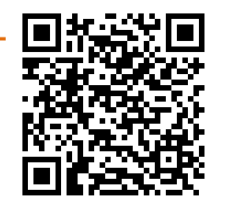

Social

\title{
SCHOOL HEAD STRATEGIC MANAGEMENT IN DEVELOPING EDUCATION PROFESSIONALITY
}

\author{
Muntholib ${ }^{1}$, Hidayat ${ }^{2}$, Jaya ${ }^{3}$ \\ ${ }^{1}$ Professor in Postgraduate UIN Sulthan Thaha Syaifuddin Jambi \\ ${ }^{2}$ Lecturer in Postgraduate UIN Sulthan Thaha Syaifuddin Jambi \\ ${ }^{3}$ Lecturer in UIN Sulthan Thaha Syaifuddin Jambi
}

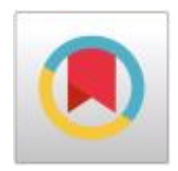

\begin{abstract}
The Government has established qualifications and competency standards for education personnel, including Minister of Education Regulation No. 24/2008 concerning school administrative staff competencies, Minister of Education Regulation No.26/2008 concerning laboratories competence, Minister of Education Regulation No. 27/2008 concerning school counselor competencies. School education personnel who have met these standards can be said to be professional education staff. To meet these standards, principals must take special steps, hereinafter referred to as strategic management.

This study aims to determine and study the empirical picture of the strategic problems faced by Jambi City 1 High School, Muara Bungo 1 High School and Sungai Penuh City 1 and Sungai Penuh School and the strategy undertaken in responding to the needs of the development of education staff in the future to respond to global competition. This research uses a qualitative method with a descriptive approach, with data collection techniques using interviews, observation and document studies. Data analysis is performed through data display, data reduction and data verification processes.

The results of this study are generally the state of professionalism of the teaching staff in Jambi Province State Senior High School not all meet the standards set by the Government. The strategic management of the headmaster of SMA Negeri 1 in Jambi Province begins with a school selfevaluation. The results of the school self-evaluation serve as a reference for the school principal in the formulation of the school's vision, mission and goals as well as the principal's policy in developing professionalism of the teaching staff.
\end{abstract}

Keywords: Strategic Management; Professional Education Personnel.

Cite This Article: Muntholib, Hidayat, and Jaya. (2019). "SCHOOL HEAD STRATEGIC MANAGEMENT IN DEVELOPING EDUCATION PROFESSIONALITY." International Journal of Research - Granthaalayah, 7(12), 271-284. 10.29121/granthaalayah.v7.i12.2019.321. 


\section{Introduction}

\section{Background}

The concept of self-determination theory which states that if a person or a group has the authority to make their own decisions, then a person or group will have a great responsibility to carry out what has been decided. The concept will not be realized maximally without the ability of the principal in managing educational institutions. There are still many managers who also do not understand and actualize the correct management concept, so that managers tend to be what they are and are just waiting for instructions from superiors without any effort to develop themselves. Quality education in a school can be realized by taking into account the management problems at the school. Management at the school includes management of Human Resources (HR) and management of Non-Human Resources. Both areas of management are important, but it should be noted that without good HR management, the non-HR components that are available in good condition will certainly not be of much benefit either. The issue of HR management occupies a strategic position in an effort to produce quality education, because it will directly affect the sustainability of school organizations.

Seeing the importance of human resources in the context of the education system, the development of human resources must really be done well. The development of human resources in a school organization, is not just the procurement of human resources, but integrated actions of various management functions so that my human resources of education can develop themselves.

Islam as a religion which kaffah has discussed earlier is related to the development of human resources. The position of Muslims as human resources is referred to by the Koran as the best people. And more specifically called human ulul albab, namely the generation of khoiro ummah (the best of the people), who became ummatan wasathan (chosen people) and became shuhada 'ala an-nas (being a witness to humans).

Other education personnel are tasked with carrying out administration, management, development, supervision and technical services to support the educational process. Other education personnel consist of 1) educational functional staff such as supervisors, supervisors, researchers and developers in the field of education 2) librarians, 3) educational technical personnel such as laboratory assistants and learning resource technical personnel 4) education unit management personnel such as school principals, directors, chairpersons, rector, 5) administrative staff such as education administration staff. In implementing the school administration system, the existence of education personnel is very important, starting from the library manager, the finance department, to the cleanliness section of the school, which is a synergistic unity that brings the school in achieving educational goals.

The school principal can also be called an educational staff, because he is an educational organizer who occupies structural positions. Especially when new government regulations emerge about the structural position of the principal. Government Regulation Number 19 of 2017 article 54 concerning Amendments to Government Regulation Number 74 of 2008 concerning teachers stating the provisions of school principals are no longer required to teach to fulfill the requirements for professional allowance. In PP No. 19 of 2017 it is stated, the workload of principals is fully carrying out managerial tasks, entrepreneurship development, and supervision of teachers and 
education staff. With this new regulation, it is hoped that school principals will be more focused on the field of education management and school administration for the realization of better school organizations.

SMA Negeri 1 Jambi City, SMA Negeri 1 Muara Bungo and SMA Negeri 1 Sungai Penuh are schools that have similar management, namely educational institutions that emphasize quality control in the education system. These high school schools display a different figure from other educational institutions, both in terms of structuring the physical appearance of the school, the substance of the curriculum, and the education management system. Based on BAN PT documents, all three schools received an A accreditation.

From the documents of these three schools it can also be seen that one of the goals of these three schools is to develop the competency of the teaching staff. This can be seen from the vision, mission and goals of the school in three schools. From the school documents, it can also be seen that the quantity of leadership staff, such as administration and technical services, such as librarians and learning resources, is sufficient. However, in terms of professional qualifications have not shown the level of professionalism.

This was justified by the headmaster of Muaro Bungo Public High School 1, who stated that there were only 2 education staff with educational qualifications in accordance with their jobs. Of the 15 education staff, starting from TU to cleaning service, at SMA Negeri 1 Muaro Bungo, 2 of them are civil servants. The same thing was expressed by the headmaster of SMA Negeri 1 Kota Sungai Penuh, stating that the problem of administrative staff at SMA Negeri 1 Kota Sungai Penuh is an educational background, the ability to develop themselves related to tasks and staff who do not yet have a high work culture. That was also stated by the headmaster of Jambi City High School 1, who stated that the level of capability of technical staff still needed guidance so that it could improve its performance.

Based on preliminary observations, researchers observed at 3 State High Schools with almost the same condition. Looks neat library condition. The books are arranged in shelves according to the theme of the book. However, researchers do not see well-organized cataloging. The books that are arranged are not in accordance with the catalog number printed on the book catalog card. The library catalog is very important because it can help readers find the book they are looking for quickly. Besides being useful for readers, catalogs also make it easier for librarians and library staff to compile and inventory library books.

In order to carry out its role and function as a manager, school principals must have the right strategy to empower education staff through cooperation or cooperation, provide opportunities for education personnel to improve their profession, and encourage the involvement of all education personnel in various activities that support school programs.

The steps to be taken by the school principal in increasing the professionalism of their teaching staff are as follows; First, empowering education staff through cooperation or cooperation, with the intention that in enhancing the professionalism capabilities of the teaching staff in schools, the principal must prioritize collaboration with education staff and other parties involved in carrying out each activity. As a manager, the principal must be willing and able to utilize all the school's 
resources in order to realize the vision, mission and achieve goals. The principal must be able to work through other people (their representatives) and try to account for all their work. The principal must be able to deal with various problems in school, think analytically and conceptually, and must always try to be an intermediary in solving various problems faced by the education staff who are subordinates, as well as trying to make decisions that satisfy all.

Secondly, it provides an opportunity for educational staff to improve their profession, develop their potential optimally, for example, provide opportunities for subordinates to improve their profession through various upgrading courses and workshops in accordance with their respective fields. Third, encourage the involvement of all education personnel, meaning that the head must strive to encourage the involvement of all education personnel in every activity (participatory). Based on observations of school document data at the SMA Negeri 1 Kota Jambi, SMA Negeri 1 Muara Bungo and SMA Negeri 1 Kota Sungai Penuh, over the past five years there has been an increase in the salary increase of both the staff and librarians. This shows the principal's management strategy to increase the professionalism of the teaching staff. In addition, the school principal also sent the head of the TU to actively participate in workshops and training related to school administration, both conducted by the Ministry of Education and from the provincial government of Jambi.

This is in line with what was conveyed by the headmaster of SMA Negeri 1 Jambi City who said that: "The school's cultural environment is an important thing to understand, by knowing the interests and needs of our employees and staff we can move them to do the tasks for which they are responsible. ".

The same thing was conveyed by the head of Muara Bungo City High School 1 stating that:

"We all know that state schools are schools whose funding is borne by the government. But the current school organization must be likened to the company system, if we cannot compete we will not be looked at by people. For that we must provide the best school services for students. In order for school services to be carried out properly, they must be supported by qualified teaching staff. The ability of educational staff can develop if we can provide understanding to them that the importance of duties and responsibilities. Besides that we also have to provide opportunities to be able to develop their abilities by engaging in workshops and training activities in accordance with their respective duties. "

The confirmation given by the head of SMA Negeri 1 Sungai Penuh shows that the management strategy he uses in order to develop the professionalism of the teaching workforce is to give full responsibility to his subordinates to complete their respective duties. According to him with the education staff, starting from the deputy head of the school to the errand boy, felt responsible and worked not only on the basis of orders. However, the principal also cannot lose control in supervising and evaluating the work of subordinates.

The steps of the principals in the 3 high schools show that the principal has conducted an analysis of the internal and external environment of the school which is the initial step of strategic management in developing the professionalism of the teaching staff. By analyzing the internal and external environment of the principal, he directly knows the strengths, weaknesses, opportunities 
and threats that are owned and faced by the school regarding the education staff that are their subordinates.

\section{Formulation of the Problem}

1) How is the strategic management carried out by school principals related to education personnel in SMA Negeri 1 Kota Jambi, SMA Negeri 1 Muaro Bungo and SMA Negeri 1 Kota Sungai Penuh?

2) What is the state of professionalism in the performance of the teaching staff of SMA Negeri 1 Kota Jambi, SMA Negeri 1 Muaro Bungo and SMA Negeri 1 Kota Sungai Penuh?

3) What is the implementation strategy of the school principal in developing the professionalism of the teaching staff in SMA Negeri 1 Kota Jambi, SMA Negeri 1 Muaro Bungo and SMA Negeri 1 Kota Sungai Penuh?

\section{Theoretical Studies}

\subsection{Strategic Management}

Strategic management is a concept originating from the private sector and being introduced to the public sector after the development of managerialism "in the discipline of state administration. Because both work in a very dynamic environment with a very high degree of uncertainty. Managers in the public sector adopt a strategic management approach to help clarify stakeholder expectations, communicate the direction of strategic policy in the internal environment and at the same time demonstrate to the environment outside the organization their ability to understand and control environmental developments.

Murniati and Usman said that Strategic Management is an activity that must be completed by top management together with personnel continuously, and is a cycle that is capable of giving birth to decisions to meet the relevance of organizational needs to environmental needs. Strategic Management is known as the science of the formulation, implementation and evaluation of crossfunctional decisions that enable an organization to achieve its objectives. Strategic Management is a combination of management, marketing, accounting, research operations, and development and information systems to achieve organizational success. Strategic management is large-scale planning (called strategic planning) oriented toward the far-reaching future (vision), and determined as top management decisions (decisions that are fundamental and principle), to enable organizations to interact effectively (mission) in an effort to produce something (operational planning to produce goods or services and services) of quality, directed at optimizing the achievement of objectives (strategic objectives) and various goals (operational objectives) of the organization.

The description explains that Strategic Management is management related to efforts to decide on strategic issues, planning, and how the strategy can be implemented in an implementative form. Strategic Management is a system that as a whole has various components that influence each other and move together in the same direction. The first component is strategic planning (strategic planning) with elements consisting of vision, mission, strategic objectives and the main strategy (parent) of the organization. The second component is operational planning (renop) with target 
elements or operational objectives, implementation of management functions in the form of organizing functions, implementation functions and budgeting functions, situational policies, internal and external networks, control and evaluation functions and feedback (feed-back).

Based on the description of the theory above, it is synthesized that strategic management in this research is a process carried out to manage the organization's strategy in developing the strength of the organization to exploit opportunities that arise in order to achieve its objectives set in accordance with the specified mission. Strategic management indicators consist of setting goals, conducting environmental analyzes, formulating plans, formulating strategies for implementing plans, and formulating decision making strategies.

\subsection{Professionalism of Educational Personnel}

Profession comes from the Latin proffesio which has two meanings namely promise / promise and work. A profession is a job that requires training and mastery of a specific knowledge and expertise. A profession usually has a professional association, a code of ethics, and a process of licensing and licensing that is specific to that profession. Likewise, Kevin Riyan, defines the profession as a collection or set of work that builds a very specific set of norms that comes from its specific role in society. Law Number 14 of 2005 Chapter I Article I paragraph 4 is described as work or activities carried out by a person and a source of living income that requires expertise, skills and skills that meet certain quality standards and norms and require professional education. A profession is a position or occupation that demands expertise or skills from the culprit.

In terminology, professional means an individual who has a profession that is done by relying on the ability and high expertise in it. Tilaar explained that a professional conduct his work in accordance with the demands of the profession or in other words has the ability and attitude in accordance with the demands of his profession. Professional has a meaning that refers to the designation of the person who bears a profession and the designation of one's appearance in realizing performance in accordance with his profession. This "professional" appearance and appearance has received recognition, both formally and informally.

A professional is someone who lives by practicing a particular skill or by engaging in a certain activity according to expertise, while others do the same thing as just a hobby, for fun, or to fill free time. Professional means expert in the field. The term professional applies to all officers from the top level to the bottom level. If a person claims to be a professional he must be able to show that he is an expert in his field. Must be able to show high quality in his work.

From the above explanation it can be concluded that the profession can be interpreted in general and special terms. In the general sense of the profession are all fields of work that are carried out with no amateur, whereas in the special sense of the profession is a job that requires special expertise obtained through certain binding education and has a certain code of ethics. While a person's mindset in carrying out his profession is called professional. a professional said if that has a mindset that is manifested in activities that bring income to him. Therefore, the higher the level of professional individuals, the more the quality of society is also increasingly high. 
The professionalism reflects a person's attitude towards his profession. Simply put, professionalism is defined behavior, ways, and qualities that characterize a profession. A person is said to be professional if his job has the technical or ethical standard of a profession. A professional runs his activities based on professionalism, and not in an amateurish manner. Professionalism is contrary to amateurism. A professional will continuously improve the quality of his work consciously, through education and training.

Professionalism can be interpreted as a person's abilities and skills in doing work according to their respective fields and levels. Professionalism is the condition, direction, values, goals, and quality of expertise and authority related to one's livelihood. Professionalism refers to the commitment of members of a profession to improve their professional abilities and continuously develop the strategies that they use in doing work that is consistent with their profession. This commitment is shown by his pride as a professional, continuous efforts to develop professional abilities.

From the opinions expressed above, it can be synthesized that what is meant by the professionalism of the teaching staff in this study is the special skills and expertise possessed by the teaching staff in their field of work in carrying out their duties optimally in achieving the goals set. The indicators of professionalism of educational staff are having professional certificates, working full time, living with the profession, mastering basic tasks and functions.

\section{Research Methodology}

This research uses a descriptive qualitative research approach. Descriptive method is a method that describes the symptoms that exist at the time of the study. Qualitative research is a research procedure that produces descriptive data in the form of written or oral words from people or actors that can be observed. According to Lexy $\mathbf{J}$ Moleong that descriptive qualitative research is a researcher looking for and using descriptive data in the form of words or expressions, opinions from research informants both oral or written. According to Arief Furchan that descriptive research is research designed to obtain information about the status of symptoms when the research is conducted. This research is expected and directed to apply the nature of a situation at the time of the investigation. In descriptive research no treatment is carried out or given or controlled as can be found in experimental research.

In this study, researchers did not give special treatment to research subjects. Researchers only explore information about symptoms that arise on the subject of research. This study was designed to find information about the symptoms that arise related to human resources in Education at the SMA Negeri 1 Kota Jambi, SMA Negeri 1 Muaro Bungo and SMA Negeri 1 Kota Sungai Penuh. It is expected that with the information about the education staff available at the 3 State High Schools, the principal's strategic management process can be seen in increasing the professionalism of the teaching staff.

\section{Research Findings and Analysis}

Law No. 20/2003 concerning the National Education System states that national education functions to develop capabilities and shape the dignified character and civilization of the nation in the context of developing the intellectual life of the nation. While the purpose of national education 
is to develop the potential of students to become human beings who believe and devote to God Almighty, have good character, are healthy, knowledgeable, capable, creative, independent and become democratic and responsible citizens. National education in Indonesia based on Pancasila and the 1945 Constitution is expected to prepare students to become citizens who have a strong and consistent commitment to defend the Unitary State of the Republic of Indonesia.

School as a formal educational institution that is a place for organizing education for the community (students) in an organized manner, has a strategic role in providing constitutionally conscious education for students. Schools have a legal and moral obligation to always provide information to the public about the importance of constitutional awareness in the life of the nation and state. In an effort to prepare future generations, it is clear that various preparatory efforts are needed that lead to the process of constitutional awareness raising for citizens. Therefore, education must be given early, in this case as an effective vehicle through schools.

The definition of educators and education personnel as stipulated in RI Law Number 20 concerning the National Education System Article 39 paragraphs (1) and (2) are as follows:

1) Educational staff are tasked with carrying out administration, management, development, supervision, and technical services to support the education process in the education unit.

2) Educators are professionals who are tasked with planning and implementing the learning process, assessing learning outcomes, conducting mentoring and training, and conducting research and community service, especially for educators at tertiary institutions.

From the definition above, it can be seen that the functions of the teaching and educational staff support each other. An education will not run well without the support of professional educators and educators.

According to Government Regulation No. 19/2005 concerning National Education Standards (SNP), the understanding of educator and education personnel standards is pre-service education criteria and physical and mental worthiness as well as education in office. Educational staff consists of the principal, administrative staff, library staff, laboratory staff, cleaning staff, and school security staff.

Educational staff is a determining factor in the success of education. Because the assessment of educational success must be viewed from various perspectives. Starting from setting an organized learning schedule, completeness of school facilities and infrastructure that are adequate and meeting the standards, cleanliness and comfort of the school environment that must be maintained, strict school management and strict supervision, and of course a quality learning process. All of these factors are the strategic role of the education staff, whether they are TU staff, librarians, laboratory assistants and school attendants / guards. To realize the goal of national education, education personnel must have the appropriate competencies including education staff in schools. The Government, through the Minister of Education and Culture, has set competency standards that must be possessed by education personnel based on Minister of Education Regulation No. 24/2008 concerning school administration staff competencies, Minister of Education Regulation No. 25/2008 concerning school library personnel, Minister of Education Regulation No. 26 Tahun 2008 on the competence of laboratory personnel, Minister of Education Regulation No. 27/2008. This standard reference must be met by schools in realizing professionalism of teaching staff. 
The existence of schools that can not realize the education staff in accordance with existing regulations will make the education staff provide educational services to teachers and students become less professional. Principals as managers in their institutions are required to carry out strategic steps in fulfilling maximum educational services including in developing the professionalism of the teaching staff.

However, the lack of professionalism of the teaching staff, especially in Jambi Province, cannot be blamed entirely on the principal. Budgeting problems and meeting the needs of formation and the welfare of education staff also become a polemic in running education programs. Until now, the fulfillment of the formation needs of educational staff at the State Senior High School has not been opened while many of the teaching staff have retired. So that the school principal puts the education staff out of line with his educational background. Circumstances that certainly do not seem to be able to fully meet the educational staff as mandated in accordance with existing regulations.

School principals must continue to innovate for the betterment of the school, not bureaucrats who merely obey the instructions of their superiors. The concept of school as stated above refers to the concept of effective school, which is a school that has a strong profile: independent, innovative, and provides a conducive climate for its citizens to develop a critical, creative, and dynamic attitude. Such schools have a strong accountability framework to students and citizens through the provision of quality services, and not merely the accountability of the government through its compliance with guidelines.

This concept is based on "self determination theory" which states that if a person or group has the authority to make their own decisions, then the person or group will have a great responsibility to carry out what has been decided. The concept will not be realized optimally without the ability of the principal in managing educational institutions. There are still many managers who also do not understand and actualize the correct management concept, so that managers tend to be what they are and are just waiting for instructions from superiors without any effort to develop themselves.

From the description above, it is very clear how the minimum standards that must be owned by educators and education staff. They are demanded to always improve their professionalism so that they become a qualified educational staff so that they can become one of the indicators in guaranteeing the quality of education.

The quality of education personnel must always be improved so that national education goals can be realized. In general, there are several strategic steps that can be implemented in an effort to develop the professionalism of teaching and education staff. These strategies include the following:

\section{Self Assessment}

Conduct self-evaluation through a meeting with brain storming (brainstorming) which is followed by the principal, the teacher, all staff, committee members, or also the foundation, for example the headmaster as the chair of the meeting starts with the question: do we need to improve quality? what is the condition of our school in terms of quality at this time ?, why is our school not / not yet qualified? This self-evaluation activity is a reflection / introspection to raise awareness / 
concern about the importance of quality education, thereby creating a shared commitment to improve quality (sense of quality), as well as formulating a point of departure for schools to develop themselves, especially quality.

\section{Formulation of Vision, Mission, and Objectives}

The formulation of the vision and mission and objectives are the initial steps that must be taken to explain the direction of education that the founders / education providers want to go. The principal and teachers must sit with the parents of students, school committees, and representatives of the local community to formulate where the school will be taken to the future which must be in accordance with the national education goals stated in Law No. 23 of 2003 concerning the National Education System.

\section{Implementation}

Implementation is a process in which organization, direction / mobilization or leadership and control / supervision are carried out as well as evaluation. In the implementation phase, it will be answered how all management functions as a process to achieve the goals set through collaboration with others and with existing resources can run as it should (effectively and efficiently). Implementation Process activities realize what has been planned.

\section{Evaluation}

Evaluation is an important activity to find out the progress or results achieved by the school in carrying out its functions according to the plans that have been made by each school. The evaluation carried out is a comprehensive evaluation involving the management of all fields in the education unit, namely the educational technical field, the field of personnel, the financial sector, the field of infrastructure and administration of school management.

\section{Reporting}

Reporting is the provision or delivery of written and official information to various stakeholders (stakeholders), regarding the management activities of education units and the results achieved within a certain period of time based on plans and rules that have been established as a form of accountability for the tasks and functions carried out by the education unit.

To implement the strategies mentioned above there must be a role for several factors, namely:

\section{The Role of the Principal}

The principal as a manager is responsible for the implementation of management functions, and as a planner must identify and formulate the results of work that are achieved by the school and identify and formulate ways (methods) to achieve the expected results. Roles in this function include: setting goals and standards, setting rules and work procedures at school, making plans, and forecasting what will happen for the future.

\section{The Role of Educational Personnel}

Educational staff have a role in managing the learning process, must understand the vision and mission of the school, synergize with the principal so that the school's goals can be easily achieved. 


\section{Government}

The government has a long-term role, namely by seeking policies that strengthen the resources of the teaching workforce by means of strengthening the education system and education staff who have expertise. Improving the quality of the teaching workforce requires the development of the expertise of educators for the following reasons: (1) the skills needed to achieve success will be higher and change very quickly, (2) the expertise required is highly dependent on new technologies and innovations, so much of that expertise must developed and trained through on-the-job training, and (3) the need for expertise is based on individual expertise. Based on the findings of the following research, the strategic management of the Head of State High Schools in Jambi Province was presented in the development of educational staff.

The school principal appoints a School Development Team (TPS) to carry out a School SelfEvaluation (EDS) of eight national education standards, including educational staff standards. The results of the EDS are then made into recommendations as a review of the school's vision and mission and goals, and in the context of meeting the standards of teaching staff in accordance with existing regulations.

The EDS results are also a reference for school principals in the formulation of the vision, mission and goals of the school and the principal's policy in developing professionalism of the teaching staff. Strategic implementation in the development of education personnel must be controlled and monitored, so that the output of the professionalism of education personnel can be maintained. The policies of the head of state high schools in Jambi Province in developing the teaching force include:

1) Motivating changes in educational staff in developing their professionalism

2) Clarifying job description,

3) Involvement of education personnel in each activity,

4) Increased discipline

5) Provide training and coaching to educational staff

6) Implement quality control of professionalism of the teaching staff

\section{Conclusions}

\subsection{Principal strategic management related to the Development of Educational Personnel}

\section{SMA Negeri 1 Jambi City}

The strategic management of the head of the Jambi City Public High School 1 related to the development of education personnel entered into strategic management in developing school quality. This is done by the school principal with 1) environmental observation 2) strategic formulation 3) strategic policy 4) evaluation. In its implementation, the head of Jambi City's Senior High School 1 formed a School Development Team (TPS) which conducted an analysis of eight National Education Standards including the teaching staff standard by conducting a School Self Evaluation (EDS). Then the TPS provides recommendations related to EDS to the principal for further strategic formulation in developing school programs to improve their quality, especially in the development of teaching staff. 


\section{SMA Negeri 1 Muara Bungo}

The strategic management of the head of Muara Bungo High School 1 in developing the teaching staff at Muara Bungo High School 1 first identified to see the potential and readiness of the school in managing the development of the teaching workforce based on SWOT analysis. So that the development of educational staff can be taken into account all the consequences and solutions, because good planning is one of the main elements determining the success of an organization's goals. This process also involves all elements in the school environment, the school principal, deputy head and elements of the teacher board. This is expected to be able to support activities and efforts that will be carried out effectively and efficiently in achieving the goals of managing the development of the education staff of SMA Negeri 1 Muara Bungo.

\section{SMA Negeri 1 Kota Sungai Penuh}

The strategic management of the headmaster of SMA Negeri 1 Kota Sungai Penuh departs from the vision and mission of the school. The principal conducts the development of the teaching staff by analyzing the teaching staff, strengths, weaknesses of opportunities and threats. From this environmental analysis the head of SMA Negeri 1 Sungai Penuh makes a formula regarding the development of the teaching force, policies related to the development of the teaching force, the implementation of the development and always controlling the educational personnel development programs.

\subsection{State of the Professional Performance of the Educational Personnel}

The state of professionalism of Jambi City High School 1, Muara Bungo High School 1 and Sungai Penuh High School, based on the analysis of Minister of Education Regulation No. 24/2008 concerning School Administration Staff Competition, Minister of Education Regulation No. 25/2008 concerning School Library Staff, Minister of Education Regulation Number 26 of 2008 concerning Laboratory Staff Competition, Minister of Education Regulation Number 27 of 2008 concerning School Counselor Competitions. The state of education staff in the three schools in general still does not meet the competency standards in accordance with the Minister of Education and Culture Regulations, both for library staff, counselors, laboratory assistants and special service officers. Most education personnel do not yet have certificates as set standards.

\subsection{Strategic implementation of School Principals in Developing Professionalism in Education Personnel}

\section{SMA Negeri 1 Jambi City}

The strategic implementation of the headmaster of SMA Negeri 1 Kota Jambi in developing the professionalism of the teaching staff is to implement the policies of the headmaster in relation to the development of the teaching workforce. In addition, the head of Jambi City's SMA Negeri 1 always communicates with the Jambi Provincial Education Office regarding the development of education personnel. The policies of the head of Jambi City Senior High School 1 in the development of teaching staff are: 1) clarifying job discribtion, 2) involvement of teaching staff in every activity, 3 ) increasing discipline. The internal communication made by the head of the Jambi City Public High School 1 to the Jambi Provincial Education Office is in the framework of; 1) welfare improvement, 2) additional development fund allocation, 3) fulfillment of educational staff needs. 


\section{SMA Negeri 1 Muara Bungo}

Strategic implementation in the development of professionalism of teaching staff in SMA 1 Muaro Bungo begins with School Self-Evaluation of the eight National Education Standards. The school development team formed by the Principal analyzes the eight national education standards, then provides recommendations for developing the quality of each standard. This includes the standards of educators and education personnel. The results of these recommendations are then combined to become a reference in preparing school work plans in the form of RKT, RKJM and RKAS. After the school work plan is prepared, school programs are a priority to be implemented.

The next step is for the school principal to provide training and guidance to the education staff. Training and coaching conducted by the head of SMA Negeri 1 Muaro Bungo so that education staff are able to follow the development of science and technology, then apply it in the context of school development. Associated with their rights, article 30 paragraph 2 of law no. 2 of 1989 states that education personnel have the right to obtain career guidance in accordance with their work performance. While article 31 paragraph 4, states that education staff are obliged to increase professional abilities in accordance with the demands of the development of science and technology and the development of the nation. So, fostering professionalism of education staff (with career expectations increasing) in accordance with the needs of the school and at the same time in accordance with the rights they receive.

To control the performance of the teaching staff, the head of SMA Negeri 1 Muara Bungo, implemented the quality control of the professionalism of the teaching workforce by: 1) determining work targets, forming a school development team (TPS) to analyze eight national education standards and providing recommendations on improving quality standards, including the standards of educational staff. From the results of this recommendation compiled the division of tasks of educational staff and job descriptions of educational staff in accordance with the Ministry of Education and Culture, 2) the principal clarifies the tasks of each educational staff by sticking job descristion in the room of each educational staff, 3) the principal always control the performance of education staff by looking at the records of service work that has been done by education staff on a daily basis, 4) the headmaster compares the records of the workforce of education staff with the job describing of each education staff 5) the school principal provides performance appraisals to education staff 6) the head The school delegates to its representatives and the head of the TU to make corrections to educational staff who do not do work according to their respective work standards.

\section{SMA Negeri 1 Sungai Penuh}

Strategic implementation Principals in developing the professionalism of the teaching staff are: 1) planning for change, 2) motivating change and 3) encouraging changes in the teaching workforce in developing their professionalism.

\section{References}

[1] Marylene Gagne, The Oxford Handbook of Work Engagement, Motivation, and Self-determination Theory, (New York, Oxford University Press. 2014)

[2] Muhaimin, dkk, Manajemen Pendidikan, Aplikasinya dalam Penyusunan Rencana Pengembangan Sekolah/Madrasah, Cetakan ke-5 (Jakarta, Prenada Media, 2015). 
[3] A.L Hartani, Manajemen Pendidikan, (Yogyakarta; Laksbang Presindo, 2011)

[4] Anonim, Peraturan Pemerintah Nomor 19 Tahun 2017 tentang Guru

[5] Lampiran Penetapan Hasil Akreditasi SMA dan SMK Provinsi Jambi Tahun 2015

[6] Dokumen Sekolah SMA 1 Kota Jambi, SMA 1 Muaro Bungo, SMA 1 Kota Sungai Penuh

[7] Wawancara tanggal 21 Januari 2017

[8] Wawancara tanggal 30 Februari 2017

[9] Wawancara tanggal 1 Januari 2017

[10] Observasi tanggal 1 Januari, 21 Januari dan 30 Februari 2017

[11] Mulyasa, Menjadi Guru Profesional. (Bandung: PT. Remaja Rosda Karya, 2005)

[12] Dokumen Sekolah SMA 1 Kota Jambi, SMA 1 Muaro Bungo, SMA 1 Kota Sungai Penuh

[13] Wawancara tanggal 1 Januari 2017

[14] Wawancara tanggal 21 Januari 2017

[15] Wawancara tanggal 30 Februari 2017

[16] Muniarti dan Nasir Ustman, Implementasi Manajemen Strategik dalam Pemberdayaan Sekolah Menengah Kejuruan, (Bandung, Citapustaka Media Perintis, 2013).

[17] Ordonez de Pablos dan Patricia, International Business Strategy and Entrepreneurship: An Information Technology Perspective (USA. Business Sience Reference, 2014)

[18] Jeffrey S. Harrison, Caron H. St. John, Foundations in Strategic Management, (Canada, Cengage Learning, 2013)

[19] Michael A. Hitt, R. Duane Ireland, Robert E Hoskissin. Concepts Strategik Management Competetiviness \& Globalization (New York, Change Learning, 2011).

[20] Sudarman Danim, Inovasi Pendidikan dalam Upaya Peningkatan Profesionalisme Tenaga Kependidikan, Cetakan IV (Bandung: CV. Pustaka Setia, 20014),

[21] Michael Young \& Johan Muller, Knowledge, Expertise and the Professions (London; Routledge, 2014)

[22] Kevin Ryan \& James Cooper, Those Who Can, Teach The Thirteen Edition (New York: Cengage Learning, 2014)

[23] Anonim, Undang-Undang Republik Indonesia Nomor 14 Tahun 2005 tentang Guru dan Dosen

[24] Yunus Namsah, Profesionalisme Guru (Jakarta: Rineka Cipta, 20015)

[25] Rusman, Belajar \& Pembelajaran: Berorientasi Standar Proses Pendidikan (Jakarta; Prenada Media, 2017)

[26] Suyanto dan Asep Jihad, Menjadi Guru Profesional: Strategi Meningkatkan Kualifikasi dan Kualitas Guru di Era Global. (Jakarta; Esensi Erlangga Group, 2013)

[27] Aholiab Watloly, Tanggung Jawab Pengetahuan: Mempertimbangkan Epistemologi Secara Kultural (Yogyakarta; Kanisius, 2013)

[28] Achmad S. Ruky, Sukses Sebagai Manajer Profesional Tanpa Gelar, (Jakarta; Gramedia Pustaka Utama, 2012)

[29] Raymond S.Pfeiffer, Ralph P. Forsberg, Ethics on the Job: Cases and Strategies Fourth Edition (USA; Cengage learning, 2014)

[30] Paul Banfield \& Rebecca Kay, Introduction to Human Resource Management Second Edition (New York, Oxford University Press, 2012)

[31] Nurul Zuhriah, Metodologi Penelitian Sosial dan Pendidikan (Jakarta: Bumi Aksara, 2006)

[32] Lexi J. Moleong, Metode Penelitian Kualitatif (Bandung: Remaja Rosdakarya, 2004)

[33] Arief Furchan, Pengantar Penelitian dalam Pendidikan (Yogyakarta: Pustaka Pelajar, 2005) 